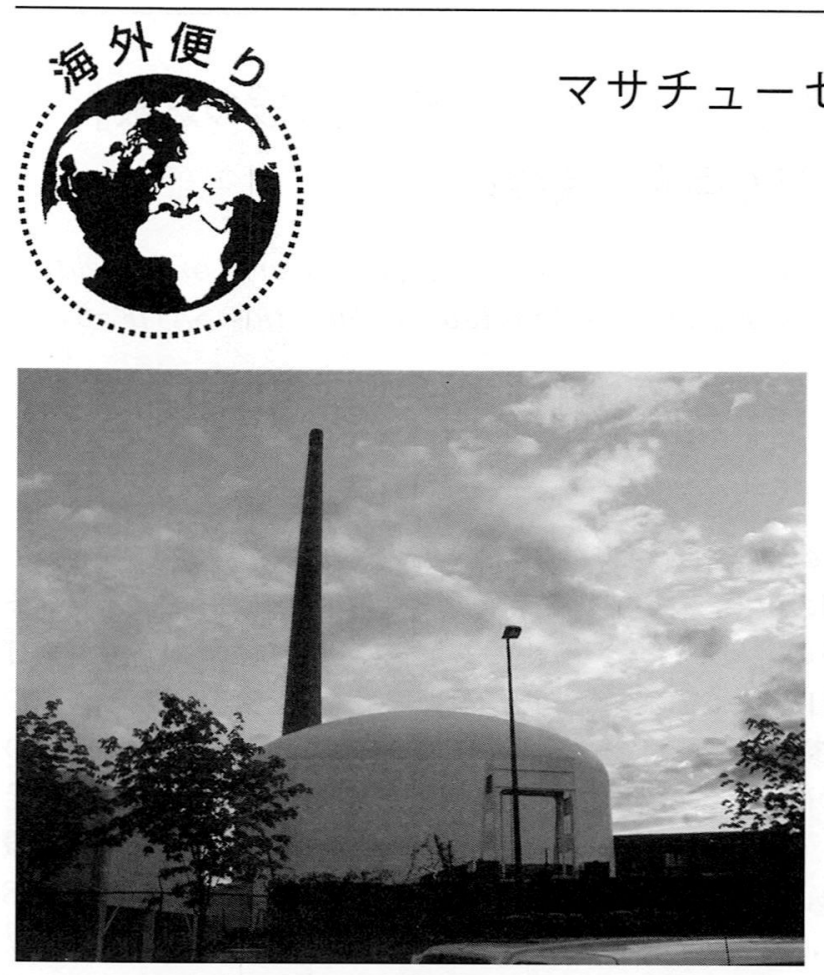

MTT 原子炉

\section{NED での研究生活}

2001年 9 月より 1 年間，米国ボストンのマサチュー セッッ工科大学 (MIT) 原子力工学科 (NED) に研究員と して在籍しております。今回は, NED, 研究プロジェ クト，ボストンでの研究生活を紹介いたします。

NED では，新型原子炉設計，伝熱流動，PSA，核融 合に始まり，医療利用，中性子散乱，社会科学と，多岐 にわたる研究を実施している(http://web.mit.edu ned $/ \mathrm{www} /)$ 。週 1 ～ 2 回開催される研究セミナー (NED 他，国立研究機関からも講演者招聘)への参加を通じ, これら幅広い分野の研究に触れる機会を得ている。とり わけ，私の専門分野 (炉物理，伝熱流動，安全設計) と全 く異なる分野(例えば，社会科学系：米国における原子 力世論形成ダイナミズムなど) と接することは, 新鮮な 驚きとともに好奇心を沸き起こしてくれる。Graduate Student は, 中国からの留学生が(圧倒的に)多く, 他は イタリア, フランス, チェコ, それにトルコ, アルゼン チンなどから。日本人留学生も在籍。

\section{米国流システム的発想との出会い}

私は, 新型ガス冷却高速炉の設計研究プロジェクト (INERIの一環。リーダー：Todreas, Driscoll 両教授)に 参加している。この炉の特徵は, 原子炉出口温度を550 ${ }^{\circ} \mathrm{C}$ と抑えるも，高圧 $(19 \mathrm{MPa}) \mathrm{CO}_{2}$, ガスタービン Brayton Cycle 採用により小型・高熱効率 $(45 \%)$ プラン トが実現可能な点と, Matrix 型燃料(黒鉛ブロック状合 金中に燃料粒子を分散させたイメージ)により冷却材跙 失直後の崩壊熱「蓄積」を可能にし，除熱猶予期間を確保 する点にある。

本プロジェクト開始と同時に私が渡米という状況で, 本年度は熱・核・プラント設計それぞれで多様な概念を
探る段階。炉概念が固まる前ということで，いろいろア イデアを提案・試設計できる一方, 議論を通じ概念自体 が大きく変遷，それへの対応が大変な場合もある。

私自身のテーマは, 本概念における経済性 (比出力向 上) と安全性 (受動的崩壊熱除去システム採用)を両立さ せる熱設計条件の検討であり，これまでの研究経験 (大 学：超臨界圧軽水炉概念設計, サイクル機構：ナトリウ 厶燃焼・熱流動評価)を活用する機会を得ている。これ までのところ, いろいろな燃料形態 (Matrix Pin 型, Ceramic Metal 燃料)および受動的崩壊熱除去システム (Open/Loop/Closed 型)の概念ごとの分類と特徴(利 点・点)の要約, ガス $\left(\mathrm{CO}_{2}, \mathrm{He}\right.$, 空気) 間の自然対流 による崩壊熱除去特性の差異と除熱限界, 定常 - 過渡設 計限界とそれを満足する炉心熱設計を実施しており， ANS 会議などを通じて公開される予定である。

研究を進める過程で, 米国の得意とするシステム的発 想を体感することが何度かあった。例えば, 崩壊熱除去 システムの検討では, まず(1)既存/新規アイデアに対し,

(2)「崩壊熱は燃料から環境へ」という観点からシステム を概念的に分類, さらに(3)各分類の熱経路を伝熱機構 (伝 導, 対流, 輻射など)へ分解, という手順をたどった。 燃料・圧力容器, 格納容器, 安全装置からなるシステム 全容を概念的に分類し, (日本だと「だめじゃないかな」と 除外されるものを含め) 総括的に考えていく経験は新鮮 であった。日本であれば, ある具体的な設計条件から徐々 に条件を代え優れたものに「育てて」いく，いわばローカ ルミニマムにたどり着こうとするのに対し，こちらで は, 全体枠を捉えた上でシステムを特性ごとに分解・分 類し, グローバルミニマムを含みそうな場所に「飛び込 む」, というイメージである。コッコッ型農耕民族と，

一発型狩猟民族の相違であろうか。

ここボストンは数多くの大学・美術館・劇場が集まる と同時に, 野球(Red Sox), アメフト(Patriots), バス ケット，アイスホッケーと 4 大スポーツが集う米国でも 稀有の地である。が, MIT の研究者は皆, クリスマス 年末・年始なぞ関係なく働いており，今のところ余り縁 が無い状況である。

最後に，異国の地で長期間 幼子を連れての研究生活は, 私なりに苦労を伴う経験で あったが，原子力の研究を続 ける中でこの機会が与えられ たことに感謝しており, 今後 米国で研究・留学される方の 参考に，私の経験をお伝えす ることができればと考えてお ります。

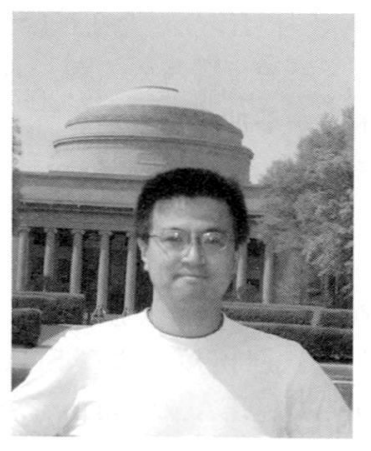

